\title{
Phytochemical and Biological Properties of Sesquiterpene Constituents From the Marine Red Seaweed Laurencia: A Review
}

\section{Shaza M Al-Massarani*}

Department of Pharmacognosy, Pharmacy College, King Saud University, Riyadh, Saudi Arabia

\begin{abstract}
Laurencia is an important marine red algal genus comprising of approximately 130 taxonomically accepted species. Compounds isolated from Laurencia species display a variety of biological activities, viz., antiviral, antibacterial, antifouling, antifungal, antioxidant, antifeedant, antimalarial, anthelmintic, antiasthmatic and cytotoxic activities. Sesquiterpenoids with, various classes and skeletons, are the main constituents of this genus. This review article has surveyed the relevant literature on Laurencia genus from January 2000 to May 2014 from the phytochemical and pharmacological viewpoints. All sesquiterpene compounds reported from this genus, during the mentioned period, are categorized according to their chemical class and general structural type. More than 200 sesquiterpenes isolated from Laurencia red algae are discussed in term of their structural type, occurrence and reported pharmacological activity.
\end{abstract}

Keywords: Laurencia; Sesquiterpenes; Marine algae; Seaweed

\section{Introduction}

The genus Laurencia, commonly known as red seaweeds, is a marine algae belonging to family Rhodomelaceae [1]. Laurencia has been established by JV Lamouroux in 1813, with only 8 species originally recognized. At present $\sim 430$ described species are identified, of which 134 are, taxonomically, accepted [2]. Seaweeds of the Laurencia genus have a wide geographical distribution and occur in all oceans and seas at all attitudes particularly in temperate to tropical shores constituting a considerable part of the flora [3]. It is estimated that over 60 species throughout the world have been investigated and more than 700 compounds possessing unique structural features have already been isolated from red algae of genus Laurencia [4]. In particular, species of Laurencia are known to be the richest producers of halogenated secondary metabolites with diverse and unique structural features depending on species, localities and season [5]. Laurencia species produce bromine-containing compounds in much larger numbers than either chlorine- or iodine-containing ones whereas, the $\mathrm{Cl}$ containing compounds usually also possess $\mathrm{Br}$ atom(s) [6]. A large number of these compounds have been obtained from Laurencia species having an intracellular, membrane-bound vesicles known as "corps en cerise" (cherry bodies) in the outer cell layer (the cortical layer) where, these inclusions are considered as a synthesis and/or storage sites of halogenated secondary metabolites [7]. On the other hand, Laurencia species without "corps en cerise" does not produce any halometabolites [8].

Laurencia chemistry is dominated by the presence of sesquiterpenes which are the most abundant members in the terpenoid groups isolated from this genus, with relatively fewer reports of diterpenoids, triterpenoids, steroids, alkaloids and C15 acetogenins [9]. Many of these compounds which exhibit significant ecological role as anti-epibiosis [10] are also reported to possess a variety of biological effects, such as cytotoxic activity against various cancer cell lines [11,12], antiviral, antibacterial, antifouling, antifungal, antioxidant, antimalarial, anthelmintic, antiasthmatic, antifeedant and other activities [13-19].

More than 200 sesquiterpenoidal metabolites, isolated from Laurencia, will be discussed, in term of their occurrence, structural type and reported pharmacological activity and presented in an order based on their general structural type. Table 1 summarizes the taxonomical position of genus Laurencia. On the other hand, alphabetical listing of all cited species with the corresponding compounds isolated from each and the related references is presented in Table 2.

\section{Sesquiterpene Constituents of Genus Laurencia}

The genus Laurencia is the most attractive source of sesquiterpenes among all marine macroalgae. It has a remarkable capacity to biosynthesize a huge variety of structurally diverse sesquiterpenes, with varied skeletons including chamigrane, bisabolane, laurane, snyderane brasilane along with some unique rearranged derivatives occurring prevalently [20,21] (Table 1).

\section{Chamigrane Skeleton Sesquiterpenes}

Spirane type sesquiterpenes -chamigrenes-are the most widespread sesquiterpenes from the genus Laurencia. Over the last twenty years, large number of structurally novel chamigrane metabolites has been isolated from Laurencia [21]. In 1970, a brominated ketone spirolaurenone (1), was the first reported chamigrane sesquiterpene; obtained from the neutral essential oil of Laurencia glandulifera (Japan) [22]. The Chinese L. okamurai, collected from the coast of Rongcheng, China, was the source of laurokamin A (2), laurokamin B (3), laurokamin C (4), 10-bromo- $\alpha$-chamigrene (5), 10-bromo$\beta$-chamigrene (6), 2,10-dibromo-3-chloro- $\beta$-chamigrene (7), and obtusane (8) [23]. Compounds 6, 7 (named as nidificene) and 8 were earlier described from L. mariannensis, in addition to (-)-(10R)-

\begin{tabular}{|l|l|}
\hline Domain & Eukaryota \\
\hline Kingdom & plantae \\
\hline Subkingdom & Biliphyta \\
\hline Phylum & Rhodophyta \\
\hline Subphylum & Rhodophytina \\
\hline Class & Florideophyceae \\
\hline Order & Ceramiales \\
\hline Family & Rhodomelaceae \\
\hline Genus & Laurencia \\
\hline
\end{tabular}

Table 1: Taxonomical Position of Laurencia.

*Corresponding author: Shaza M Al-Massarani, Department of Pharmacognosy, Pharmacy College, King Saud University, Riyadh, Saudi Arabia, Tel: 96-6114960-181; E-mail: salmassarani@ksu.edu.sa

Received May 29, 2014; Accepted August 18, 2014; Published August 20, 2014

Citation: Shaza M Al-Massarani (2014) Phytochemical and Biological Properties of Sesquiterpene Constituents From the Marine Red Seaweed Laurencia: A Review. Nat Prod Chem Res 2: 147. doi:10.4172/2329-6836.1000147

Copyright: (c) 2014 Shaza M Al-Massarani. This is an open-access article distributed under the terms of the Creative Commons Attribution License, which permits unrestricted use, distribution, and reproduction in any medium, provided the original author and source are credited. 
Citation: Shaza M Al-Massarani (2014) Phytochemical and Biological Properties of Sesquiterpene Constituents From the Marine Red Seaweed Laurencia: A Review. Nat Prod Chem Res 2: 147. doi:10.4172/2329-6836.1000147

Page 2 of 13

\begin{tabular}{|c|c|c|}
\hline Species & Sesquiterpene constituents & Reference \\
\hline L. aldingensis & aldingenins A-D (75-78) & {$[63,64]$} \\
\hline L.cartilaginea & isorigidol (46), ma'ilione (49) & {$[50]$} \\
\hline L. composita & $\begin{array}{l}\text { laurecomins A-D (16-19), 2,10-dibromo-3-chloro-7-chamigren-9-ol acetate (20), deoxyprepacifenol (21), 2-bromospironippol (22), } \\
\text { laurencomposidiene (23), (8ß)-10-bromo-3-chloro-2,7-epoxychamigr-9-en-8-ol (24), 2-bromo-3-chlorobisabola-7(14),11-diene-6,10- } \\
\text { diol (72), 1-bromoselin-4(14),11-diene (150) and 9-bromoselin-4(14),11-diene (151) }\end{array}$ & [29-32] \\
\hline L. dendroidea & dendroidone (51), dendroidiol (52), (205) & {$[53,110]$} \\
\hline L. glandulifera & spirolaurenone (1), laurene (90) & {$[22,70]$} \\
\hline L.gracilis & isolaurenisol, (132) reported from & [85] \\
\hline L. elata & Elatol (25), cycloelatanene A (27) and B (28) & {$[33,40]$} \\
\hline L. filiformis & $\begin{array}{l}\text { Prepacifenol (41), 5-acetoxy-2,10-dibromo-3-chloro-7,8-epoxy- } \alpha \text {-chamigrene (42), cycloisoallolaurinterol (125) isoallolaurinterol } \\
\text { (126), filiformin (127), filiforminol (128), allolaurinterol (129), 10-bromolaurenisol (130) }\end{array}$ & {$[48,82]$} \\
\hline L. luzonensis & 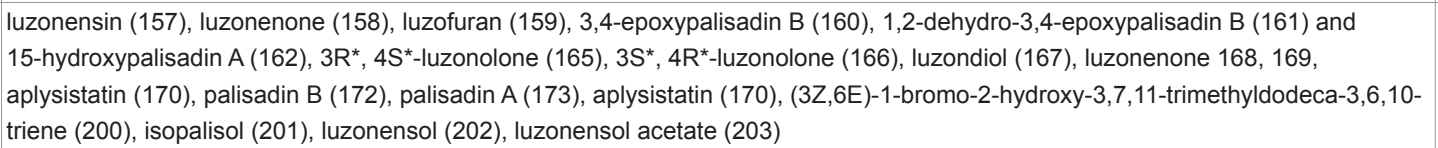 & {$[95,96,98]$} \\
\hline L. microcladia & $\begin{array}{l}\text { Elatol (25), hydroxy- } \beta \text {-bisabolene, (66), compounds 84-86 laurokamurenes A (87) and B (88), (134-137), 8-cycloeudesmane (148), } \\
\text { calenzanol (176), debromoisocalenzanol (177), (178) }\end{array}$ & $\begin{array}{l}{[34,60,67,68]} \\
{[91,102,103]}\end{array}$ \\
\hline L. majuscula & $\begin{array}{l}\text { Elatol (25), Isoobtusol (26), 8-bromochamigren-1-en (29), (6R,9R,10S)-10-bromo-9-hydroxychamigra-2,7(14)-diene (30), } \\
\text { majapolene B (197), majapolene A (198) }\end{array}$ & {$[8,41,108]$} \\
\hline $\begin{array}{l}\text { L. } \\
\text { mariannensis }\end{array}$ & $\begin{array}{l}\text { 10-bromo- } \beta \text {-chamigrene (6), 2,10-dibromo-3-chloro- } \beta \text {-chamigrene (7), and obtusane (8), (-)-(10R)-bromo-a-chamigrene (9), } \\
\text { 9-deoxyelatol (34), deschloroelatol (35), 36, 37, isoafricanol (189), isodactyloxene A (190) }\end{array}$ & {$[24,105]$} \\
\hline L. nipponica & laurene $(90)$ & [70] \\
\hline L. obtusa & $\begin{array}{l}\text { Isoobtusol (26), chamigrenelactone (31), oxachamigrene (32) and 5-acetoxyoxachamigrene (33), 12-hydroxy isolaurene (93), } \\
\text { isolauraldehyde (94), 8,11-dihydro-12-hydroxy isolaurene (95), 3,7-dihydroxydihydrolaurene (138), (139), (141-143), brasilenol } \\
\text { (144), epibrasilenol (145), (146), } \beta \text {-snyderol (152), (8R*)-8-bromo-10-epi- } \beta \text {-snyderol (154) (8S*)-8-bromo- } \beta \text {-snyderol (155), (179- } \\
\text { 182), perforenone D (183), perforatone (184), perforenol B (185), bromocyclococanol (186), 5-bromo-3-(3'-hydroxy-3'-methylpent-4'- } \\
\text { enylidene)-2,4,4-trimethylcyclohexanone (187), (188) }\end{array}$ & $\begin{array}{l}{[16,35,42,43]} \\
{[72,86,87,93]} \\
{[104]}\end{array}$ \\
\hline L. okamurai & 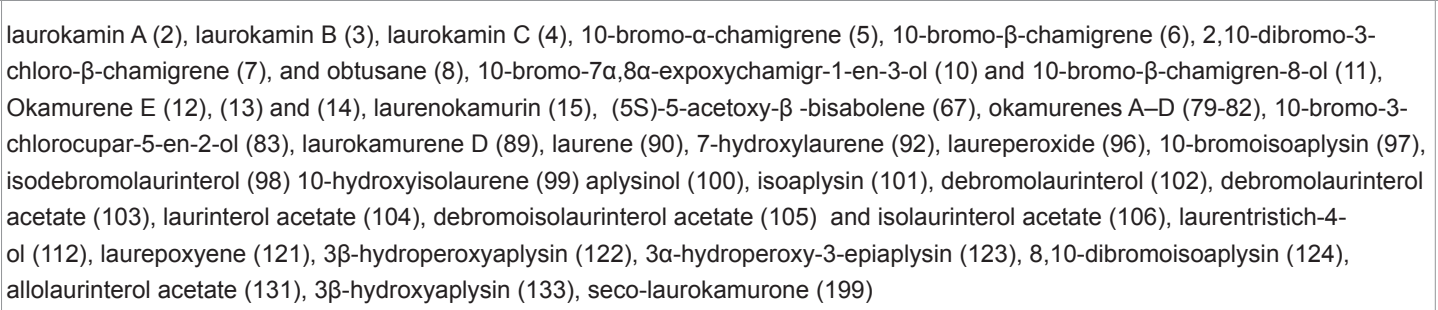 & $\begin{array}{l}{[23,25,26,28,61]} \\
{[68,71,73-75]} \\
{[78,84,88]}\end{array}$ \\
\hline L. pannosa & pannosanol (43), pannosane (44) & [49] \\
\hline L. perforata & 4-hydroxy-1,8-epi-isotenerone (191), 9-hydroxy-3-epi-perforenone A (192), 3-epi-perforenone (193) & [106] \\
\hline L. rigida & 9-deoxyelatol (34), deschloroelatol (35) & [13] \\
\hline L. saitoi & $\begin{array}{l}\text { 10-bromo-3-chloro-2,7-epoxychamigr-9-en-8a-ol (38), 2,10ß-dibromochamigra-2,7-dien-9a-ol (39), 2,10-dibromo-3-chlorochamigr- } \\
\text { 7-en-9a-ol (40), (9S)-2-bromo-3-chloro-6,9-epoxybisabola-7(14),10-diene (73) and (9R)-2-bromo-3-chloro-6,9-epoxybisabola- } \\
\text { 7(14),10-diene (74), isolaurenisol, (132), 2-hydroxyluzofuranone A (163), 2-hydroxyluzofuranone B (164), acetoxypalisadin B (174), } \\
\text { 4-hydroxypalisadin C (175), 2-bromo- }- \text {-ionone (204) }\end{array}$ & {$[45,46,97,101]$} \\
\hline L. scoparia & $\begin{array}{l}\text { Scopariol (45), isorigidol (46) (+)-3-(Z)-bromomethylidene-10 } \beta \text {-bromo- } \beta \text {-chamigrene, (-)-3-(E)-bromomethylidene-10 } \beta \text {-bromo- } \beta \\
\text {-chamigrene }(47,48)(69-71)\end{array}$ & {$[17,62]$} \\
\hline L. similis & 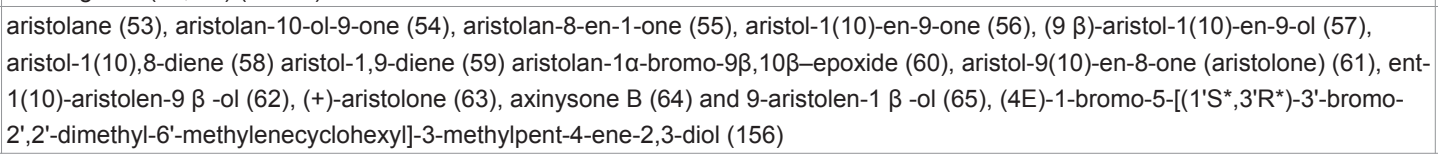 & $\begin{array}{l}{[55,56,58]} \\
{[94]}\end{array}$ \\
\hline L. subopposita & 7-hydroxylaurene (92) & [71] \\
\hline L. snackeyi & Aplysistatin (170), 5ß-hydroxypalisadin B (171) & {$[99,100]$} \\
\hline L. snyderae & $\beta$-snyderol (153) & [93] \\
\hline L. tristicha & $\begin{array}{l}\text { ar-bisabol-9-en-7,11-diol (68), laur-11-en-2,10-diol (107), laur-11-en-10-ol (108), laur-11-en-1,10-diol (109), 4-bromo-1,10-epoxylaur- } \\
\text { 11-ene (110), cyclolauren-2-ol (111) and laurentristich-4-ol (112), aplysin (113), aplysinol (100), laurebiphenyl (114), aplysin-9-ene } \\
\text { (115), epiaplysinol (116), debromoepiaplysinol (117), -bromolaur-11-en-1,10 } \beta \text {-diol (118), 4-bromolaur-11-en-1,10a-diol (119), laur- } \\
\text { 11-en-1,10 a -diol (120) }\end{array}$ & {$[12,77,79,81]$} \\
\hline Laurencia sp. & Ma'iliohydrin (50), 8, 10-dibromo-3, 7-epoxy- laur-13-ol (140), Tiomanene (194), acetylmajapolene B (195), acetylmajapolene A (196) & {$[52,57,107]$} \\
\hline
\end{tabular}

Table 2: Sesquiterpene constituents isolated from the species of genus Laurencia.

bromo- $a$-chamigrene (9) [24]. Furthermore, 10-bromo- $7 \alpha, 8 \alpha$ expoxychamigr-1-en-3-ol (10) and 10-bromo- $\beta$-chamigren-8-ol (11) were isolated from another collection of the Chinese L. okamurai [25].
L. okamurai, collected along Weihai coastline in Shandong Province, China yielded okamurene E (12) [26]. On the other hand, compounds (13) and (14) were isolated as a 1:1 diastereoisomeric mixture from $L$. 
okamurai (Qingdao, China) [27]. The same species, L. okamurai, was also the source of the rearranged chamigrane laurenokamurin (15) [28]. L. composita collected from Pingtan Island, China yielded laurecomins A-D (16-19), 2,10-dibromo-3-chloro-7-chamigren-9-ol acetate (20) and the known compound, deoxyprepacifenol (21) [29]. Compounds $\mathbf{1 6}$ and $\mathbf{1 7}$ displayed potent brine shrimp toxicity with $\mathrm{LC}_{50}$ values of 51.1 and $37.0, \mu \mathrm{g} / \mathrm{mL}$, respectively. Additionally, compound 17 was active against the plant-pathogenic fungus Colletotrichum lagenarium with an inhibitory diameter of $10 \mathrm{~mm}$ [30]. Another Chinese $L$. composita sample (Nanji Is.) afforded 2-bromospironippol (22) and laurencomposidiene (23) (named as laurencomposene elsewhere in the same paper). The authors suggested that the occurrence of rearranged chamigranes in L. composita but not in L. okamurai could provide a useful chemotaxonomic marker to distinguish these two similar species [31]. However, several rearranged chamigranes were reported, later, from L. okamurai [26]. In 2010, a L. composita sample collected from the same area contained ( $8 \beta$ )-10-bromo-3-chloro-2,7epoxychamigr-9-en-8-ol (24) [32]. Elatol (25), isolated for the first time from L. elata in 1974 [33], was obtained in high yield of ca. 10\% $(\mathrm{w} / \mathrm{w})$ from the ethanolic extract of L. microcladia [34]. Isoobtusol (26), described originally from L. obtusa [35], was isolated together with elatol (25) from L. majuscula in waters of Sabah, Malaysia and both compounds $\mathbf{2 5}$ and $\mathbf{2 6}$ were found to be active against some marine bacteria [8]. Vairappan et al. reported significant antibacterial activity for compound $\mathbf{2 5}$ against Staphylococcus epidermis, Klebsiella pneumonia and Salmonella sp, whereas, isoobtusol was significantly active against K. pneumonia and Salmonella sp. Further tests indicated that both compounds were bacteriostatic rather than bactericidal [36]. Elatol showed potent antiproliferative activity against promastigote and intracellular amastigote forms of Leishmania amazonensis, with an $\mathrm{IC}_{50}$ of $4.0 \mu \mathrm{M}$ and $0.45 \mu \mathrm{M}$, respectively [37]. Recently, Desoti et al. reported the effective trypanocidal activity of (-)-elatol, extracted from $L$. dendroidea, against Trypanosoma cruzi. The mechanism of action was also investigated and discussed thoroughly [38]. Moreover, in-vitro and in-vivo experiments suggested that elatol acted as antitumor agent, against HeLa and Hep-2 human carcinoma cell lines, by activating the apoptotic process [39]. The Australian L. elata yeilded two C16 chamigrenes, named cycloelatanene A (27) and B (28) [40]. L. majuscula collected from the South China Sea was the source of 8-bromochamigren-1-en (29) [41], while L. majuscula from Okinawa was the source of $(6 R, 9 R, 10 S)$-10-bromo-9-hydroxychamigra-2,7(14)diene (30) in a first report of this compound from a natural source. Compound 30 showed activity against Alcaligenes aqua-marinus, Azomonas agilis, Erwinia amylovora, and Escherichia coli with MIC values in the range of $20-30 \mu \mathrm{g} / \mathrm{disk}$ [8]. A biogenetically interesting halogen-devoid metabolite chamigrenelactone (31), with a high oxygencontent, has been isolated from L. obtusa from Isla Grande (Caribbean Panama) [42]. Two sesquiterpenes with an oxacyclic chamigrene skeleton, oxachamigrene (32) and 5-acetoxyoxachamigrene (33), were isolated from a Cuban L. obtusa sample [43]. In 2007, Ji et al. reported the isolation of 9-deoxyelatol (34), deschloroelatol (35); and compounds 36 and 37 from L. mariannensis [24]. Compounds 34 and 35 were obtained, previously, from $L$. rigida (Hainan and Weizhou Islands, China) [13], while compounds $\mathbf{3 6}$ and $\mathbf{3 7}$ were reported in 1982 as intermediates in a biomimetic synthetic study of rhodolaureol and rhodolauradiol [44].

In 2009, L. saitoi (Shandong Province, China) yielded 10-bromo-3-chloro-2,7-epoxychamigr-9-en- $8 \alpha$-ol (38) and $2,10 \beta$-dibromochamigra-2,7-dien- $9 \alpha$-ol (39), in addition to the known compound 2,10-dibromo-3-chlorochamigr-7-en-9 $\alpha$-ol (40) $[45,46]$. Prepacifenol (41), originally described from a Laurencia sp. [47], and its acetate derivative, 5-acetoxy-2,10-dibromo-3-chloro-7,8-epoxya-chamigrene (42), were isolated From L. filiformis collected from Taroona, Tasmania. An X-ray analysis was reported for Prepacifenol and its NMR spectra were fully assigned for the first time. Both compounds exhibited moderate activity in the brine shrimp bioassay [48]. L. pannosa from Malaysia was the source of two halogenated chamigranes with unusual rearranged framework named pannosanol (43) and pannosane (44). Both compounds showed antibacterial activities [49]. The rearranged chamigrane Scopariol (45), the $\beta$-chamigrene isorigidol (46) and the geometric isomers (+)-3-(Z)bromomethylidene-10 $\beta$-bromo- $\beta$-chamigrene and (-)-3-(E)bromomethylidene-10 $\beta$-bromo- $\beta$-chamigrene $(47,48)$ were reported from L. scoparia collected in Brazilian waters. Compound 46 and ma'ilione (49), previously isolated from L.cartilaginea [50] exhibited moderate in vitro anthelmintic activity against the parasitant stage of Nippostrongylus brasiliensis [17]. From L. scoparia and in a separate report, Suescun et al. isolated and established the absolute stereochemistry of isorigidol (46) and ma'ilione (49) by an X-ray crystal as $(3 R, 6 S, 9 S, 10 S)$ and $(6 S, 9 R, 10 S)$ respectively [51]. Ma'iliohydrin (50), a cytotoxic tribrominated chamigrene with dibromohydrin functionality from a Laurencia sp. (Philippines) exhibited cytotoxicity in the NCI 60-cell line human tumour screen and potent activity against the NCI/ADR-RES breast cancer cell line [52]. Recently, dendroidone (51) and dendroidiol (52) were isolated from the Brazilian species $L$. dendroidea collected at Biscaia Inlet, Rio de Janeiro [53] (Figure 1)

\section{Aristolane Skeleton Sesquiterpenes}

The aristolane sesquiterpenes, derivatives of 6,11-cycloeremophilanes, are mainly reported from the species $L$. similis. A Chinese sample of $L$. similis (Hainan Is., China) yielded aristolane (53), formerly known as a synthetic compound [54], from a natural source for the first time. In addition, aristolan-10-ol-9one (54), aristolan-8-en-1-one (55), aristol-1(10)-en-9-one (56), 9 $\beta$-aristol-1(10)-en-9-ol (57), aristol-1(10),8-diene (58) and aristol1,9-diene (59) were also isolated and identified [55]. In 2010, Li et al. obtained aristolan- $1 \alpha$-bromo- $9 \beta, 10 \beta$-epoxide (60) and aristol9(10)-en-8-one (aristolone) (61) from the same species [56]. A former report published in the same year, 2010, established the isolation of $\mathbf{6 1}$ from Laurencia for the first time [57]. Recently, a Bornean L. similis population yielded ent-1(10)-aristolen-9 $\beta$-ol (62) as a new optical isomer of compound 57, in addition to $(+)$-aristolone (63), axinysone $\mathrm{B}$ (64) and 9-aristolen-1 $\beta$-ol (65) [58] (Figure 2).

\section{Bisabolane Skeleton Sesquiterpenes}

The bisabolane skeleton develops from the cyclization of the geranyl cation and results in the formation of a monocyclic ring structure [59]. In 2007, L. microcladia (Chios Is., North Aegean Sea) afforded the hydroxyl derivative of $\beta$-bisabolene, (66) [60], while, (5S)5 -acetoxy- $\beta$-bisabolene (67), was isolated, recently, from L. okamurai Yamada [61]. L. tristicha (Naozhou Island, China) yielded ar-bisabol9-en-7,11-diol (68) [12]. On the other hand, L. scoparia (S $\sim$ ao Paulo, Brazil) was the source of compounds (69-71). The confirmation of the structure and the absolute configuration of all stereo centers of $\mathbf{6 9}$ were proved by single-crystal X-ray crystallography. Compound $\mathbf{6 9}$ exhibited weak in vitro anthelmintic activity against Nippostrongylus brasiliensis [62]. L. composita from Nanji Is., China contained 2-bromo-3-chlorobisabola-7(14),11-diene-6,10-diol (72) [32], while, L. saitoi (Shandong Province, China) yielded (9S)-2-bromo-3-chloro6,9-epoxybisabola-7(14),10-diene (73) and (9R)-2-bromo-3-chloro6,9-epoxybisabola-7(14),10-diene (74) as an inseparable $1: 1$ mixture [46]. Biogenetic considerations were useful to assign the novel oxacyclic 

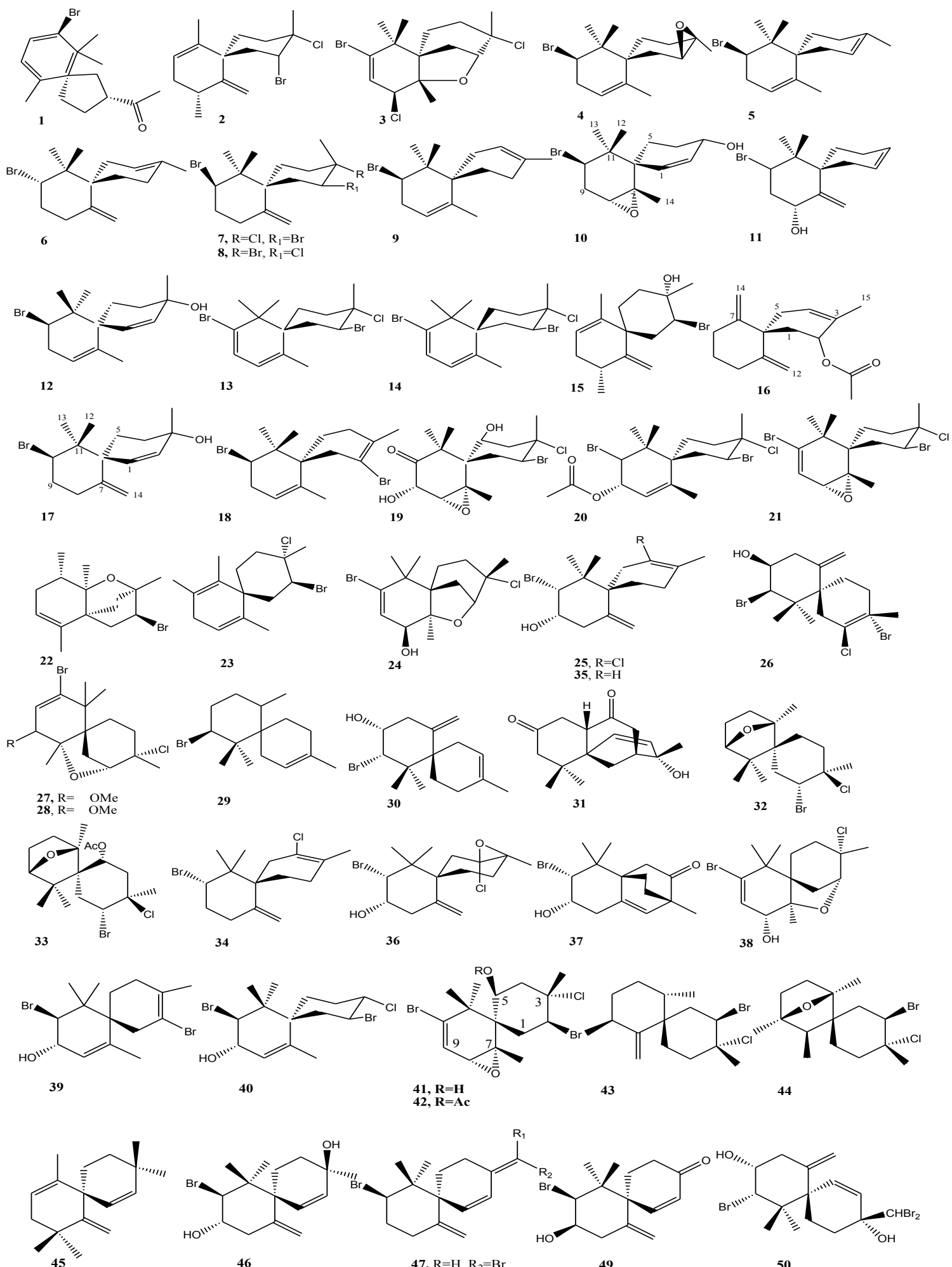

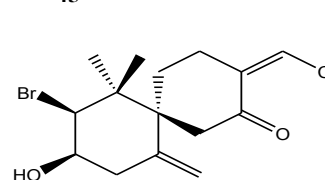

51
B

52

Figure 1: Chamigrane sesquiterpenes from Laurencia. 


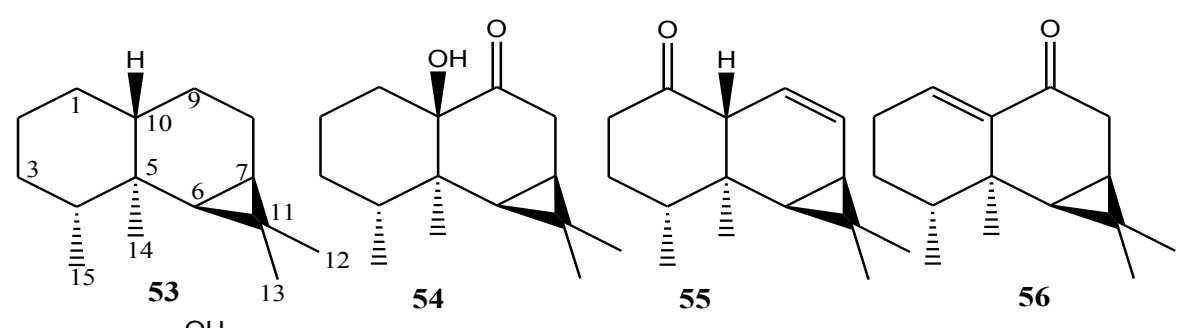<smiles>CCC1C[C@@H](O)C2=CCC[C@@H](C)[C@]21C</smiles><smiles>[2H][C@H]1CC[C@@H](C)[C@]2(C)C1=CC(=O)[C@H]1C2C1(C)C</smiles>

61, $\mathrm{R}=\mathrm{H}$ 64, $\mathrm{R}=\mathrm{OH}$<smiles>C=CC1C=CC2=CCC[C@@H](C)[C@]2(C)C1C</smiles>

58<smiles>C[C@@H]1CCC=C2[C@@H](O)C[C@H]3[C@@H](C3(C)C)[C@]21C</smiles>

62<smiles>CC1(C)[C@@H]2[C@H]1CC=C1C=CC[C@@H](O)[C@@]12C</smiles>

59<smiles>C[C@@H]1CC[C@@H](Br)[C@]23O[C@H]2C[C@@H]2[C@@H](C3(C)C)[C@]12C</smiles>
Oํ $^{\text {O0 }}$<smiles>C[C@@H]1CCCC2=CC(=O)[C@H]3C[C@]2(C)[C@]31C(C)(C)C</smiles>

63

Figure 2: Aristolane sesquiterpenes from $t$

bisabolene-type structures of aldingenins A-D (75-78), isolated from L. aldingensis (Castelhanos, Brazil) [63,64]. The okamurenes A-D (7982) were isolated from L. okamurai, whereas, okamurenes A (79) and $\mathrm{B}(\mathbf{8 0})$ were the first examples of bromobisabolanes possessing a phenyl moiety among sesquiterpenes derived from Laurencia as claimed by the authors. The isolated compounds displayed potent cytotoxicity when evaluated in the brine shrimp lethal assay [26] (Figure 3).

\section{Cuparane Skeleton Sesquiterpenes}

Cuparane skeleton is formed by cyclisation between carbons 6 and 11 of the bisabolane skeleton. In cuparane-type compounds, the three methyls in the aliphatic portion are located at positions 1, 2 and 2 [65]. In addition to marine organisms, cuparanes are found in liverworts and higher plants [66] (Figure 4).

L. okamurai, collected from the coast of Rongcheng, China, yielded 10-bromo-3-chlorocupar-5-en-2-ol (83) [25]. It is notable that most of the cuparane sesquiterpenes isolated from seaweeds have an aromatic ring such as compounds $\mathbf{8 4 - 8 6}$, isolated from the Greek L. microcladia, collected at Chios Island in the North Aegean Sea. A strong cytotoxic activity was recognized for compounds 84-86 against NSCLC-N6 and A-549 lung cancer cell lines. Compound 85 showed a unique (for the cuparene class of sesquiterpenes) migration of the C-1 methyl group. The authors speculated that the aromatic hydroxyl group increased the cytotoxicity observed in compounds $\mathbf{8 5}$ and $\mathbf{8 6}$ [67]. Later on, laurokamurenes A (87) and B (88), were isolated from L. okamurai (Nanji Is., China) [68]. In 2007, total synthesis of the ( \pm )-laurokamurene B (88) was completed, employing a combination of the Ireland-Claisen rearrangement and ring-closing metathesis reactions [69]. Lately, laurokamurene D (89) was isolated from $L$. okamurai Yamada [61] (Figure 5).

\section{Laurane Skeleton Sesquiterpenes}

In Laurane-type compounds, contrary to the cuparanes, the three methyls in the aliphatic portion are located at positions 1,2 and 3. Laurencia is considered the main producer of laurane-type sesquiterpenes among marine organisms in general [65]. The Chinese L. okamurai collected from the coast of Rongcheng, yielded laurene (90), originally isolated from L. glandulifera and L. nipponica [70], and 7-hydroxylaurene acetate (91). Compound 90 exhibited potent antibacterial activity and lethal toxicity to brine shrimp [25]. However, 7-hydroxylaurene (92) was reported in 1977 as novel compound from L. subopposita and L. okamurai [71]. The compounds 12-hydroxy isolaurene (93), isolauraldehyde (94) and 8,11-dihydro-12-hydroxy isolaurene (95), isolated from L. obtusa, exhibited potent activity against the gram-positive Bacillus subtilis and Staphylococcus aureus, with 94 being the most active (MIC of 35 and $27 \mu \mathrm{g} / \mathrm{mL}$, respectively). Compound 94 showed, also, significant activity against Candida albicans (MIC of $70 \mu \mathrm{g} / \mathrm{mL}$ ) and promising in vitro activity against Ehrlich ascites carcinoma [72].

In 2005, the Chinese L. okamurai (Nanji Island) yielded laureperoxide (96), 10-bromoisoaplysin (97), isodebromolaurinterol (98) and 10-hydroxyisolaurene (99) as new compounds together with seven previously reported and related sesquiterpenes; aplysinol (100), isoaplysin (101), debromolaurinterol (102), debromolaurinterol acetate (103), laurinterol acetate (104), debromoisolaurinterol acetate (105) and isolaurinterol acetate (106) [73-75]. In the same year, 2005, $L$. tristicha (Naozhou Island, China) was the source of laur-11-en-2,10-diol (107), laur-11-en-10-ol (108), laur-11-en-1,10-diol (109), 4-bromo1,10-epoxylaur-11-ene (110), previously reported as a synthetic racemate [76], cyclolauren-2-ol (111) and laurentristich-4-ol (112), along with the formerly known compounds aplysin (113), aplysinol (100), and the dimeric cyclolaurane sesquiterpene laurebiphenyl (114) 


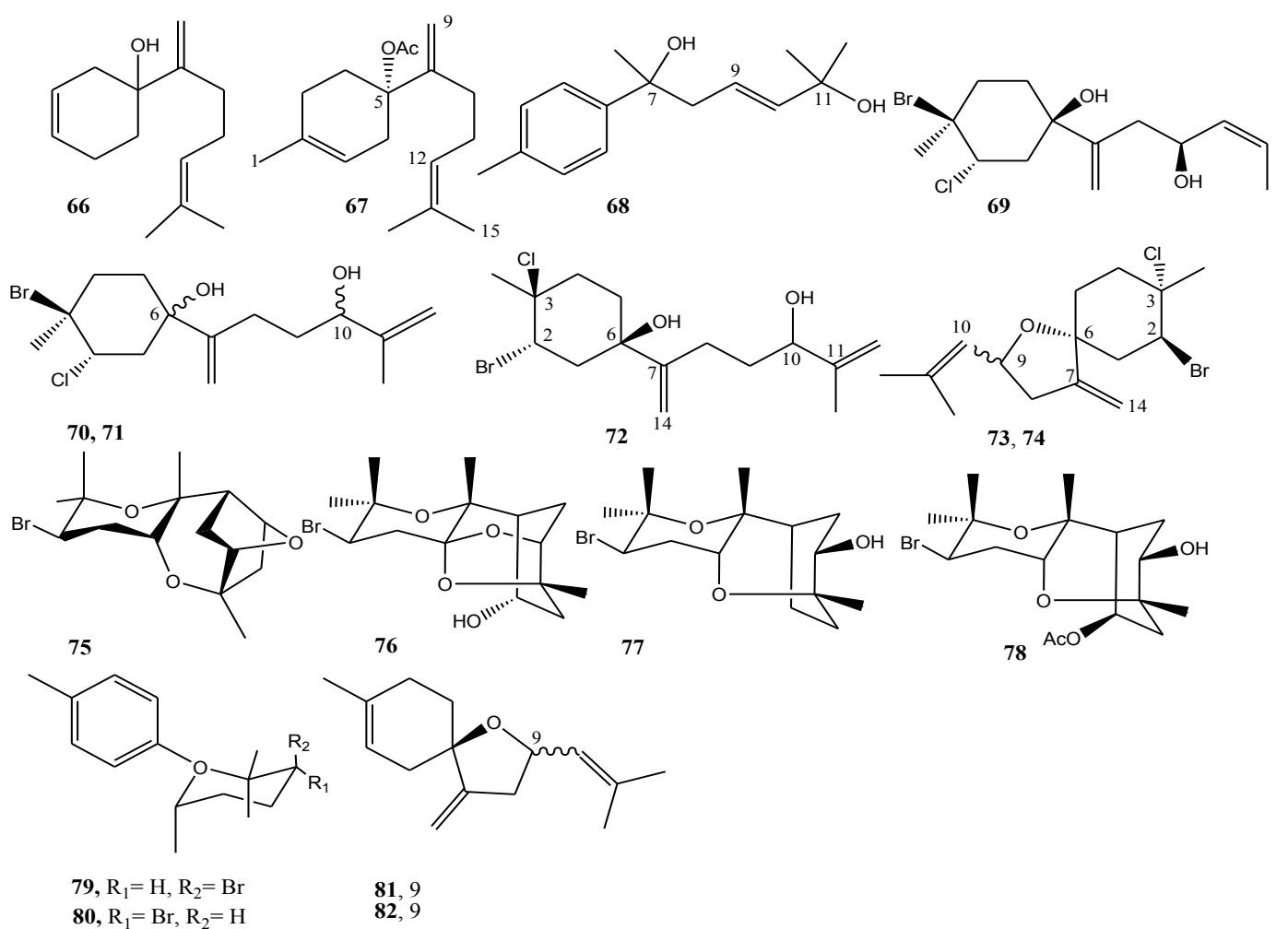

Figure 3: Bisabolane sesquiterpenes from Laurencia.

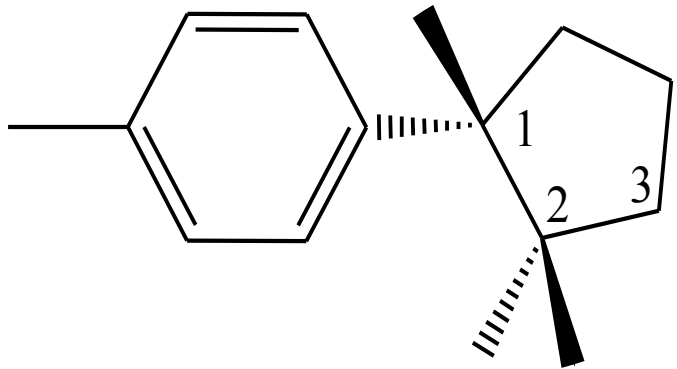

Figure 4: Structure of cuprane.

[77,12]. Compound 112, having a novel rearranged cyclolaurane skeleton was also reported recently from L. okamurai [78]. Compound 114 exhibited moderate cytotoxicity against several human cancer cell lines, while all other compounds were inactive [12]. The Chinese species L. tristicha produced aplysin-9-ene (115), epiaplysinol (116) and debromoepiaplysinol (117). Compound 117 displayed selective cytotoxicity to the HeLa cell line [79]. Another collection of L. tristicha (Shanwei, Guangdong Province, China) yielded the stereoisomers 4-bromolaur-11-en-1,10 $\beta$-diol (118) and 4-bromolaur-11-en-1,10 $\beta$ -diol (119), along with the known laur-11-en-1,10 $\beta$-diol (120), but reported for the first time as a natural product $[80,81]$.

A Chinese collection of L. okamurai (Nanji island) yielded laurepoxyene (121), $3 \beta$-hydroperoxyaplysin (122), $3 \beta$-hydroperoxy3-epiaplysin (123) and 8,10-dibromoisoaplysin (124) [61]. The Australian L. filiformis (St. Paul's Beach, Australia) produced cycloisoallolaurinterol (125) and isoallolaurinterol (126) as new compounds, along with the previously reported filiformin (127),
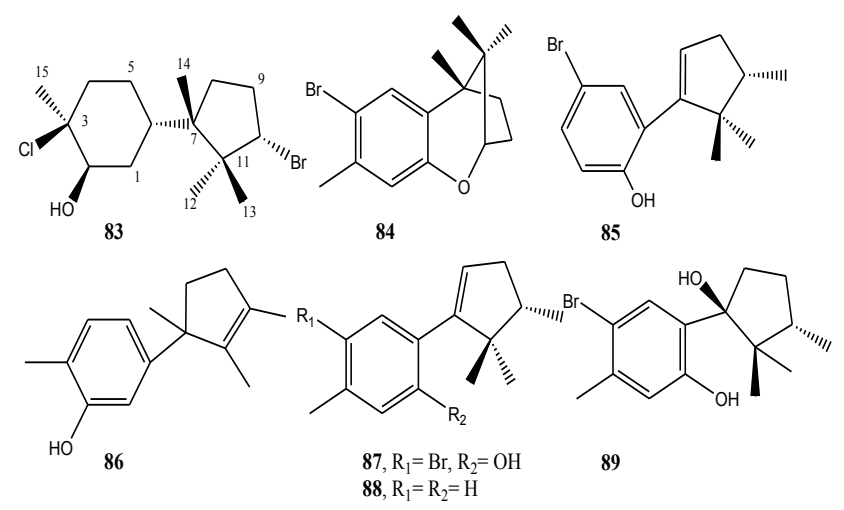

Figure 5: Cuparane sesquiterpenes from Laurencia.

filiforminol (128), allolaurinterol (129) and 10-bromolaurenisol (130) [82]. The authors suggested that both $\mathbf{1 2 5}$ and $\mathbf{1 2 6}$ are formed as artefacts from compound 129 [83]. The previously reported allolaurinterol acetate (131) [84] was isolated again in 2012 from L. okamurai [25], while, isolaurenisol, (132) previously reported from L.gracilis [85] was obtained in 2009 from L. saitoi [46]. $3 \beta$-hydroxyaplysin (133) was isolated from L.okamurai (Nanji Is., China) [68] while, L. microcladia (Chios Is., North Aegean Sea) provided the aromatic sesquiterpenes (134-136) and the dimeric brominated sesquiterpene 137 [60]. The organic extract of L. obtusa, collected from Serifos in the Aegean Sea afforded 3,7-dihydroxydihydrolaurene (138) and (139). Both compounds showed weak cytotoxic activity against five human tumour cell lines [86]. On the other hand, a Laurencia sp. collected from South 

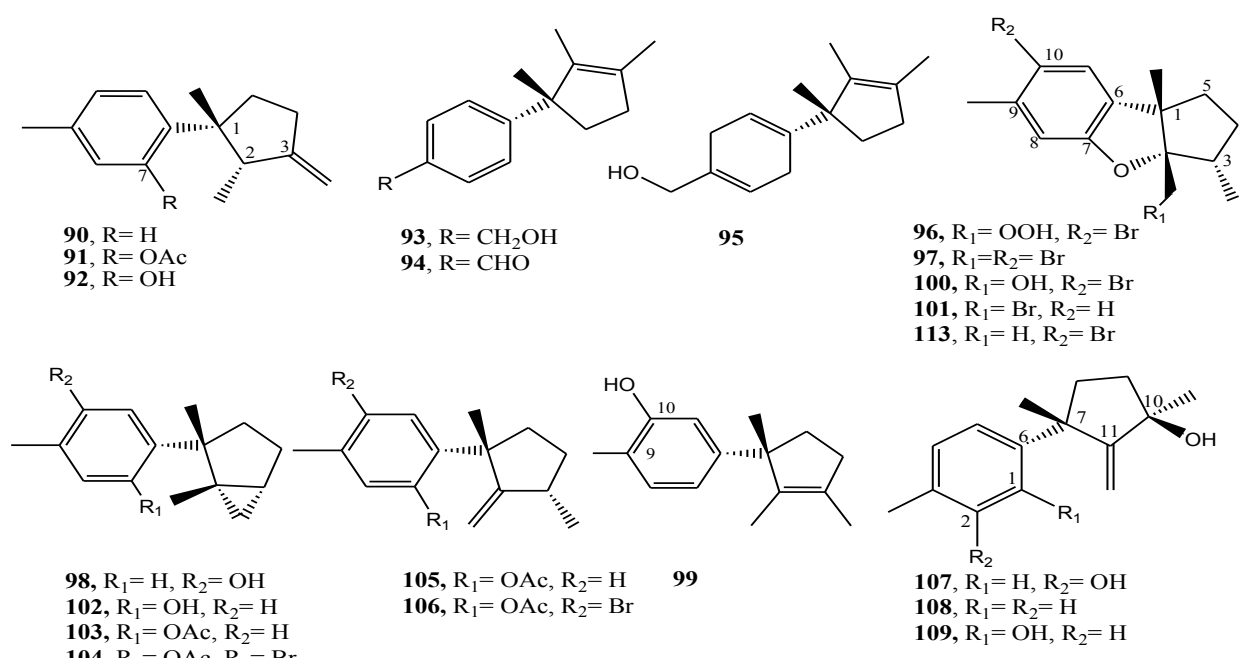

99

年, $\mathrm{R}_{1}=\mathrm{OAc}, \mathrm{R}_{2}=\mathrm{H}$

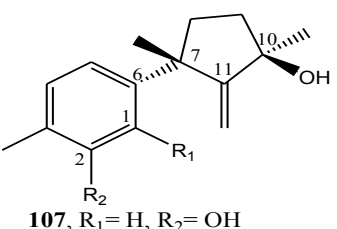

$108, R_{1}=H, R_{2}=O H$
10

109, $\mathrm{R}_{1}=\mathrm{OH}, \mathrm{R}_{2}=\mathrm{H}$<smiles>CC[C@]1(C)[C@]2(C)CC[C@]1(C)Cc1cc(C)c(Br)cc12</smiles>

110

111

112

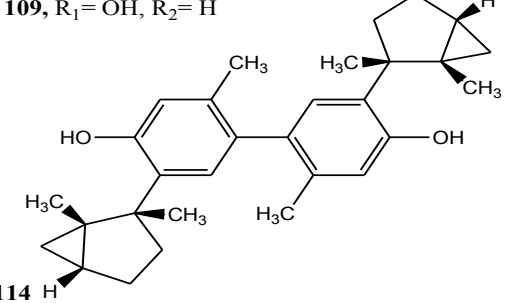<smiles></smiles>

115

116, $R=B r$
117, $R=H$

118, $\mathrm{R}=\mathrm{Br}, \mathrm{R}_{1}=\mathrm{Me}, \mathrm{R}_{1}=\mathrm{OH}$

119, $R=B r, R_{1}=O H, R_{1}=M e$
$120, R=H, R_{1}=M e, R_{1}=O H$

121<smiles>CC1=CC[C@](C)(c2cc(O)c(C)cc2O)[C@@H]1C</smiles>

122, $B$ OOH
123, $\triangle \mathrm{OOH}$

124

125

126

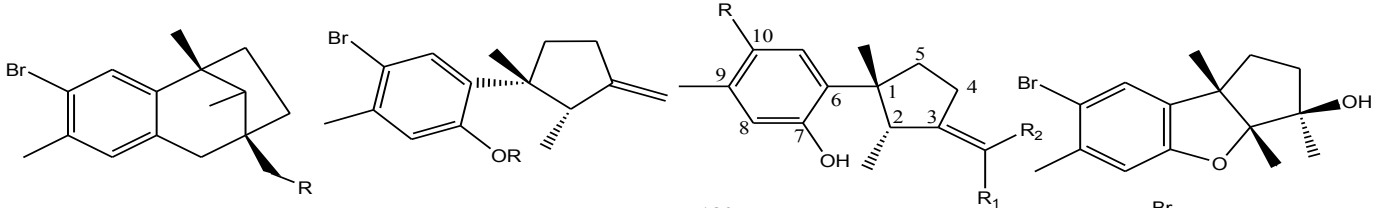

127, $\mathrm{R}=\mathrm{H}$
128, $\mathrm{R}=\mathrm{OH}$

129, $R=H$
131, $R=A c$

130, $\mathrm{R}=\mathrm{Br}, \mathrm{R}_{1}=\mathrm{Br}, \mathrm{R}_{2}=\mathrm{H}$
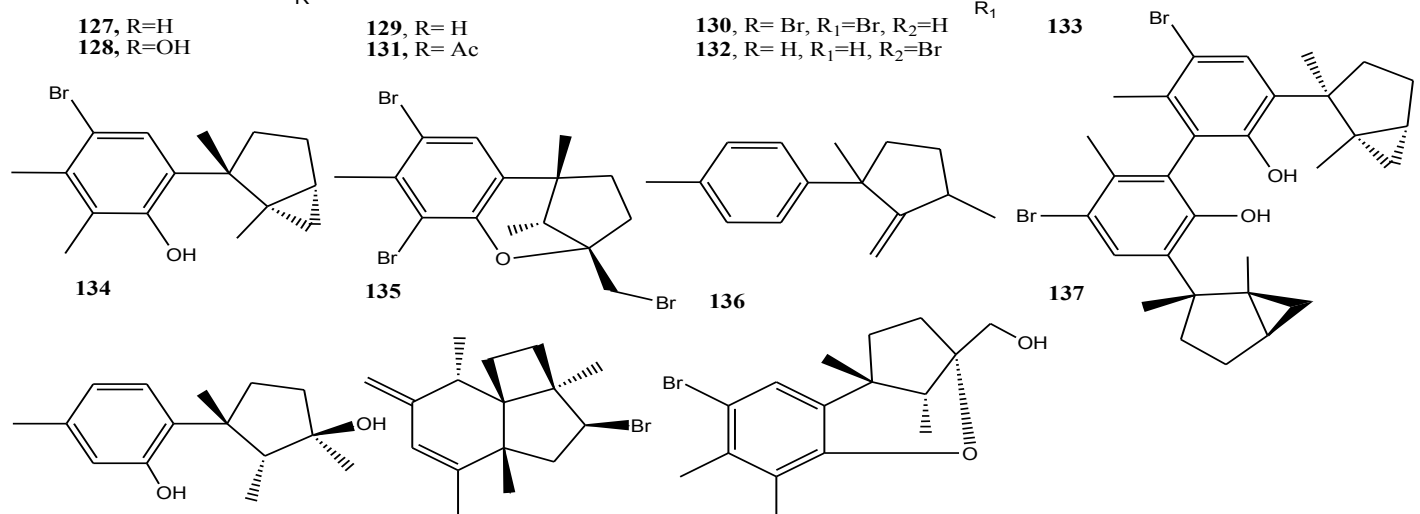

138
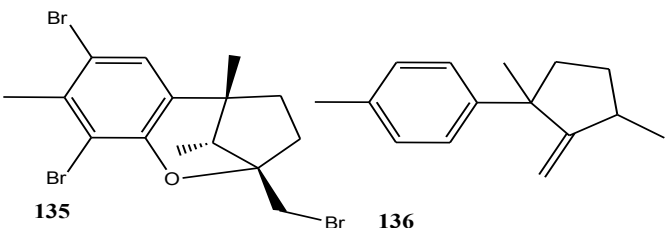

136

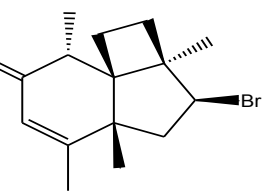

$\mathrm{Br}$

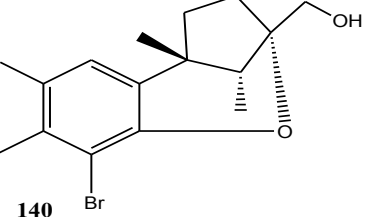

Figure 6: Laurane sesquiterpenes from Laurencia. 
China Sea was the source of 8, 10-dibromo-3, 7-epoxy- laur-13-ol (140) [57] (Figure 6).

\section{Brasilane Skeleton Sesquiterpenes}

Brasilane skeleton has the basic structure of octahydro-1,6,6trimethyl-4-(1-methyl)-1H-indene [65]. The rearranged halogenated compounds, with the unique 1,6-epoxy brasilane moiety (141-143) had been isolated; along with the known compounds brasilenol (144) and epibrasilenol (145) from L. obtusa collected off Symi Island in the Aegean Sea, Greece. Relative stereochemistries of all compounds were determined by molecular modeling [87]. L. obtusa (Tekirova, Turkey) produced also new brasilane-type sesquiterpene with the systemic name 2-Chloro-4-isopropyl-1,6,6-trimethylhexahydro- $1 H$-indene-1,3 $\beta, 7 \beta$-triol (146) [88] (Figure 7).

\section{Eudesmane (selinane) Skeleton Sesquiterpenes}

Eudesmane-type sesquiterpenes, formerly referred to as selinanes, have been recognized from several terrestrial and marine organisms and occasionally encountered from Laurencia [89]. Heterocladol (147) was the first example of a sesquiterpene with a selinane skeleton reported from Laurencia species and its structure was rationalized in terms of a trans-annular ring closure of a germacradiene [90]. $L$. microcladia, collected in the Baia di Calenzana, Elba Island, was the source of 8-cycloeudesmane (148), the first eudesmane sesquiterpene to be isolated from a marine origin [90]. In the same year, 2002, itomanol (149), was isolated from L. intricata collected in Okinawan waters [91]. In 2012, the brominated selinanes, 1-bromoselin-4(14),11diene (150) and 9-bromoselin-4(14),11-diene (151), isolated from<smiles>CC(C)C1CC(C)(I)CC2C(C)CCC12</smiles><smiles>CC(C)[C@H]1CC(C)(C)[C@H](O)C2=C1CC[C@H]2C</smiles>

144,145

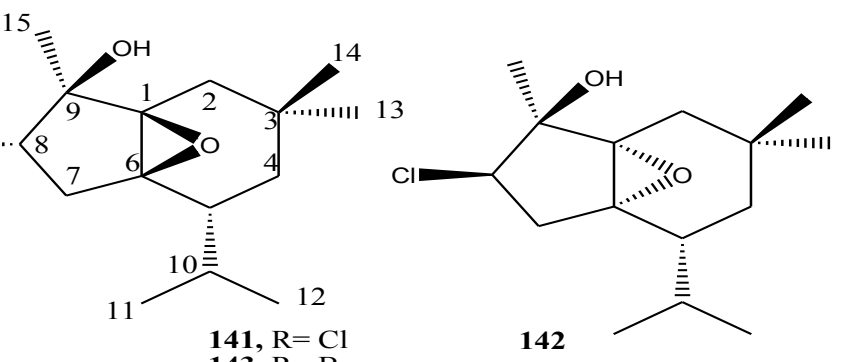

$143, \mathrm{R}=\mathrm{Br}$<smiles>CC(C)C1CC(C)(C)CC2(O)C(C)(O)C(Cl)CC12O</smiles>

146

Figure 7: Brasilane sesquiterpenes from Laurencia.<smiles>CC(C)[C@H]1CC[C@]2(C)[C@@H](Br)CC[C@](C)(O)[C@@]2(C)[C@H]1Cl</smiles>

147<smiles>C=C(C)[C@@H]1CC[C@@]2(C)[C@H](Br)CCC(=C)[C@H]2C1</smiles>

150

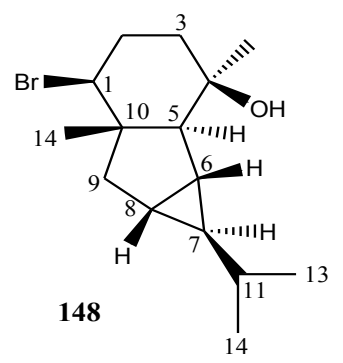<smiles>CC1=CC[C@@H](Br)[C@]2(C)CC[C@H](C(C)C)[C@H](O)[C@]12C</smiles>

149<smiles>C=C1CCC[C@]2(C)C1C[C@H](C(=C)C)C[C@@H]2Br</smiles>

151

Figure 8: Eudesmane sesquiterpenes from Laurencia. 
L. composita (Pingtan Island, China) displayed potent brine shrimp toxicity with $\mathrm{LC}_{50}$ of 15.2 and $78.7 \mu \mathrm{g} / \mathrm{mL}$, respectively [30] (Figure 8).

\section{Snyderane Skeleton Sesquiterpenes}

The snyderane sesquiterpenes are bromo monocyclo-nerolidol derivatives. $\beta$-snyderol (152) and $\beta$-snyderol (153) were the first reported compounds having this skeleton from collections of $L$. obtusa and $L$. snyderae, respectively [92]. (8R*)-8-bromo-10-epi- $\beta$-snyderol (154) and $\left(8 S^{*}\right)$-8-bromo- $\beta$-snyderol (155) were isolated from $L$. obtusa collected from Bademli, Turkey. Compound 154 was active against D6 and W2 clones of the malaria parasite Plasmodium falciparum [16].

(4E)-1-bromo-5-[(1'S*,3'R*)-3'-bromo-2',2'-dimethyl-6'methylenecyclohexyl]-3-methylpent-4-ene-2,3-diol (156) was isolated from L. similis (Sanya Bay, China) [93], while luzonensin (157) [94], luzonenone (158), luzofuran (159), 3,4-epoxypalisadin B (160), 1,2-dehydro-3,4-epoxypalisadin B (161) and 15-hydroxypalisadin
(162) were obtained from L. luzonensis, from Okinawan waters [95]. The ethanolic extract of the Chinese L. saitoi (Hainan coastline) yielded 2-hydroxyluzofuranone A (163) and 2-hydroxyluzofuranone B (164) [96]. Another collection of the Okinawan L. luzonensis, a rich source of snyderane sesquiterpenes, afforded $3 R^{\star}, 4 S^{\star}$-luzonolone (165), 3S $4 S^{\star} 4 R^{\star}$-luzonolone (166), luzondiol (167), luzonenone (158) and the two isomeric compounds 168 and 169, beside the known compound, aplysistatin (170). The authors suggested that compounds 168 and 169 were the first non-halogenated compounds, from the Laurencia genus, with a rearranged snyderane skeleton, as a result of a 1,2 methyl migration [97]. Aplysistatin (170), obtained from L. snackeyi in a bioassay-guided isolation, significantly inhibited NO and prostaglandin-E2 (PGE2) production. Activity was attributed to the modulation of anti-inflammatory agents via the inhibition of nitric oxide synthase (NOS) and cyclooxygenase-2 (COX-2) expressions in LPS-stimulated RAW 264.7 cells [98]. On the other hand, $5 \beta$-hydroxypalisadin B (171), isolated also from L. snackeyi,<smiles>C=CC(C)(O)CC[C@H]1C(C)=CC[C@H](Br)C1(C)C</smiles>

152<smiles>C=CC(C)(O)CC[C@H]1C(=C)CC[C@H](Br)C1(C)C</smiles>

153<smiles>[R9]C1C[C@@H]([18OH])C(C)(C)[C@H](CCC(C)(O)C=C)C1=C</smiles>

154, $\mathrm{R}_{1}=\otimes \mathrm{Br}, \mathrm{R}_{2}=\otimes \mathrm{Br}$ $155, R_{1}=\bigotimes B r, R_{2}=\bigotimes B r$

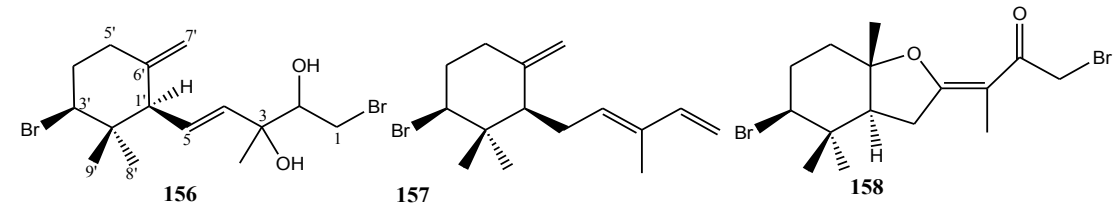<smiles>CC1(C)[C@@H]2C[C@@H](c3ccoc3)O[C@@]2(C)CC[C@H]1Br</smiles>

159

157<smiles>C[C]1CC[C@@H](Br)[C@@]2(C)OCCC12</smiles>

163<smiles>C[C@@H]1[CH]OC(=O)C1O</smiles>

164<smiles>CC1(C)[C@@H](Br)CC[C@@]2(C)O[C@H]([C@](C)(O)C(=O)CBr)C[C@@H]12</smiles>

165,166<smiles>CC12CCC(Br)C(C)(C)C(C)(C)C1CC(C(C)(O)C(O)CBr)O2</smiles>

160<smiles>CC1(C)[C@H](Br)CC[C@@]2(C)O[C@]2(C)C[C@@H]2O[C@@]21C</smiles>

161

167<smiles>[R8]C1C2CC=C3C(=N)OCC3OC2(C)CCC1(C)C</smiles>

162<smiles>CC1(C)[C@H](Br)CC[C@]2(C)O[C@H]3OCC(=[18O])C3=CC[C@H]12</smiles>

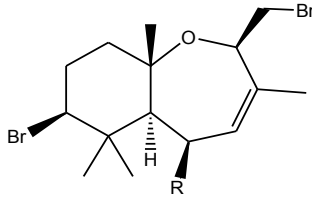

$171, \mathrm{R}=\mathrm{OH}$
$172, \mathrm{R}=\mathrm{H}$

174, $\mathrm{R}=\mathrm{AcO}$
168, $\mathrm{R}_{1}=\mathrm{OH}, \mathrm{R}_{2}=\mathrm{CH}_{3}, \mathrm{R}_{3}=\mathrm{H}_{2}$ $169, \mathrm{R}_{1}=\mathrm{H}, \mathrm{R}_{2}=\mathrm{CH}_{2}, \mathrm{R}_{3}=\mathrm{O}$<smiles>C=C1[C@H](O)C[C@@H]2C(C)(C)[C@H](Br)CC[C@@]2(C)O[C@@H]1C</smiles>

175

Figure 9: Snyderane sesquiterpenes from Laurencia. 
exhibited profound anti-inflammatory activity in lipopolysaccharide (LPS)-induced nitric oxide (NO) production in zebrafish embryo. The protective effect was comparable to the anti-inflammatory agent dexamethasone with effective concentrations of the compound between $0.25-1 \mu \mathrm{g} / \mathrm{mL}$ [99]. On the other hand, L. luzonensis was the source of palisadin B (172), palisadin A (173) and its oxidized product aplysistatin (170) [94]. L. saitoi (Hainan coastline, China) was the source of 5-acetoxypalisadin B (174) [100] and 4-hydroxypalisadin C (175) [96] (Figure 9).

\section{Other Skeletons Sesquiterpenes}

In addition to the skeletons mentioned above, there are some other sesquiterpenes, reported from different species of Laurencia that do not fit easily into the above categories.

L. microcladia, from Elba Island, provided a novel calenzanane sesquiterpene named calenzanol (176) [101]. Later, debromoisocalenzanol (177) and an indene-type sesquiterpene (178) were, also, obtained from L. microcladia, [102]. L. obtusa collected at Milos Island in the Aegean Sea Greece yielded four undecane3-one sesquiterpenes (179-182) and perforenone D (183). The relative stereochemistry of the known compound perforatone (184) was revised [87]. On the other hand, perforenol B (185), which was also, isolated from L. obtusa, exhibited strong cytotoxic activity [86]. Moreover, L. obtusa from Cayo Coco, Cuba was the source of bromocyclococanol (186), possessing a novel carbon skeleton of fused cyclopropane-cyclopentane rings [103]. The Turkish $L$. obtusa collected from Bademli, yielded 5-bromo-3-(3'-hydroxy-3'methylpent-4'-enylidene)-2,4,4-trimethylcyclohexanone (187), and the epoxide (188) [16]. The previously known as a synthetic compound, isoafricanol (189) [104] was reported from L. mariannensis (Hainan and Weizhou Islands, China) as a natural product, together with a chromene type sesquiterpene, isodactyloxene A (190) [24]. 4-hydroxy1,8-epi-isotenerone (191), 9-hydroxy-3-epi-perforenone A (192) and 3-epi-perforenone (193) were isolated from the lipophilic extract of L. perforata, collected from the Great Barrier Reef, Australia [105]. Tiomanene (194), acetylmajapolene B (195) and acetylmajapolene A (196) were isolated from an unrecorded Laurencia species collected at Pulau Tioman, Pahang (Malaysia) [106] along with the known majapolene B (197) and majapolene A (198), originally isolated from L. majuscula [107]. The use of vibrational circular dichroism (VCD) allowed the determination of the absolute configuration of 195 and 198 as $7 S, 10 S$ for both [108].

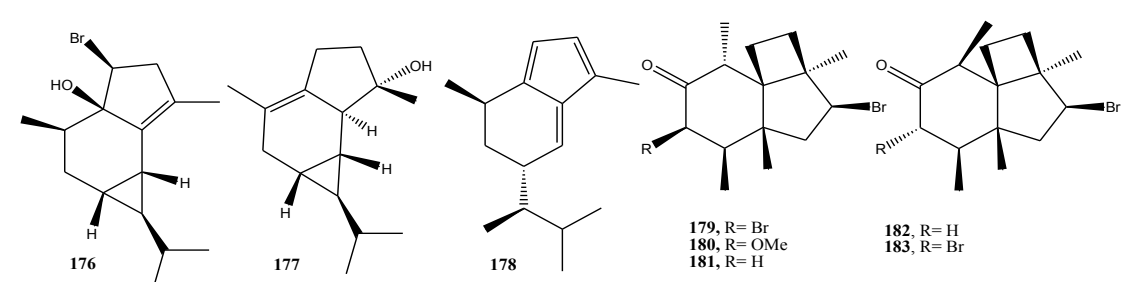<smiles>C=CC(C)(C)C/C=C1\C(C)C(=O)[C@H](C)[C@H](C)C1(C)C</smiles>

184

186<smiles>C=CC(C)(O)/C=C\[C@]12O[C@]1(C)CCCC2(C)C</smiles>

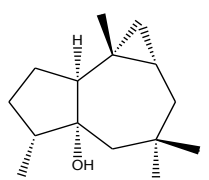

189<smiles>C=C[C@]1(C)CC[C@H]2C(C)=CC[C@@H](C)[C@]2(C)O1</smiles>

190
187

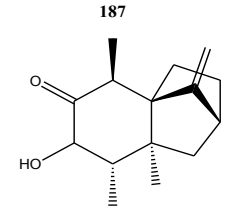

191

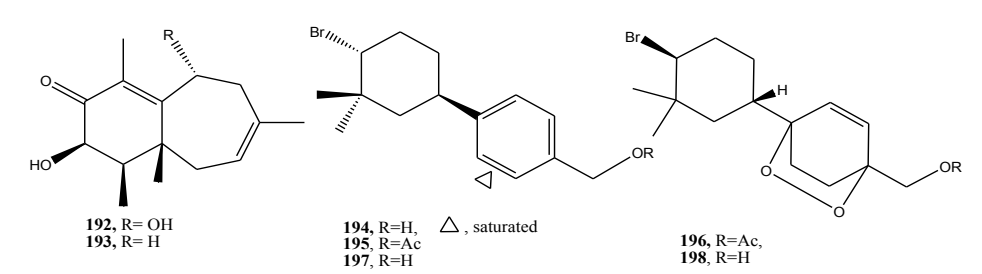<smiles>C=C1CC=CC(C)(C)C1C/C=C(\C)C(O)CBr</smiles>

199

200 201<smiles>C=C1CCCC(C)(C)[C@H]1C/C=C/C(O)C[B][C@@H]1CCC(=C)[C@@]2(/C=C/C(C)=O)[C@H]1C2(C)C</smiles>

$202, R=H$
$203, R=A c$

204

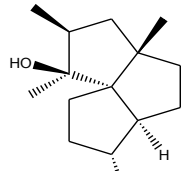

205 棓

Figure 10: Other skeletons sesquiterpenes from Laurencia. 
A ring-cleaved sesquiterpene, reported as having a novel skeleton, was isolated from L. okamurai Yamada and named secolaurokamurone (199) [61]. L. luzonensis from Okinawan waters yielded (3Z,6E)-1-bromo-2-hydroxy-3,7,11-trimethyldodeca-3,6,10-triene (200), isopalisol (201), luzonensol (202) and luzonensol acetate (203) [95], while, the norsesquiterpene derivative, 2-bromo- $\beta$-ionone (204) was isolated from L. saitoi (Hainan coastline, China) [97]. A triquinane derivative (205) was identified from $L$. dendroidea, in the Brazilian coast, and was found to be moderately active against Leishmania amazonensis $\left(\mathrm{IC}_{50} 43.8 \mu \mathrm{g} / \mathrm{mL}\right.$ ) [109] (Table 2 and Figure 10).

\section{Conclusion}

Among the red algae, genus Laurencia is known to be one of the most important resources to produce unique natural metabolites with novel structures. A large number of sesquiterpene compounds with unprecedented structural features have been described from different Laurencia species during the past years. In the present review, an attempt to congregate the phytochemical and biological information on Laurencia sesquiterpenes was conducted. Survey of literature revealed the presence of over 200 sesquiterpenoids isolated from different species, over the last 14 years, and reported either as novel or known compounds. The numerous chemical diversity and biological activities of genus Laurencia keep attracting the attentions of phytochemists and pharmacologists to further explore different species of this interesting red weed distributed in the oceans and seas around the world.

\section{References}

1. Masuda M, Kogame K, Arisawa S, Suzuki M (1998) Morphology and halogenated secondary metabolites of three Gran Canarian species of Laurencia ceramiales, Rhodophyta. Botanica Marina 41: 265-277.

2. Sentíes A, Díaz-Larrea J, Cassano V, Gil-Rodríguez MC, Mutue T, et al. (2011) Laurencia marilzae (ceramiales, rhodophyta) from the mexican caribbean: a new record for the tropical western atlantic. Bulletin of Marine Science 87: 681-686.

3. http://www.algaebase.org/

4. Suzuki M, Vairappan CS (2005) Halogenated secondary metabolites from Japanese species of the red algal genus Laurencia (Rhodomelaceae, Ceramiales. Curr Top Phytochem 7: 1-34.

5. Wang BG, Gloer JB, Ji NY, Zhao JC (2013) Halogenated organic molecules of Rhodomelaceae origin: chemistry and biology. Chem Rev 113: 3632-3685.

6. Suzuki M, Takahashi Y, Nakano S, Abe T, Masuda M, et al. (2009) An experimental approach to study the biosynthesis of brominated metabolites by the red algal genus Laurencia. Phytochemistry 70: 1410-1415.

7. Young DN, Howard BM, Fenical W (1980) Subcellular localization of brominated secondary metabolites in the red alga Laurencia snyderae. J Phycol 16: 182-185.

8. Vairappan CS, Suzuki M, Abe T, Masuda M (2001) Halogenated metabolites with antibacterial activity from the Okinawan Laurencia species. Phytochemistry 58: 517-523.

9. Amsler, Charles D (2008) Algal chemical ecology. Springer-Verlag press.

10. Cabrita MT, Vale C, Rauter AP (2010) Halogenated compounds from marine algae. Mar Drugs 8: 2301-2317.

11. Juagdan EG, Kalidindi R, Scheuer $P$ (1997) Two new chamigranes from an hawaiian red alga, Laurencia cartilaginea.Tetrahedron 53: 521-528.

12. Sun J, Shi D, Ma M, Li S, Wang S, et al. (2005) Sesquiterpenes from the red alga Laurencia tristicha. J Nat Prod 68: 915-919.

13. König GM, Wright AD (1997) Laurencia rigida: chemical investigations of its antifouling dichloromethane extract. J Nat Prod 60: 967-970.

14. Alarif WM, Al-Lihaibi SS, Abdel-Lateff A, Ayyad SE (2011) New antifungal cholestane and aldehyde derivatives from the red alga Laurencia papillosa. Nat Prod Commun 6: 1821-1824.

15. Li YX, Li Y, Qian ZJ, Kim MM, Kim SK (2009) In vitro antioxidant activity of 5-HMF isolated from marine red alga Laurencia undulata in free-radical- mediated oxidative systems. J Microbiol Biotechnol 19: 1319-1327.

16. Topcu G, Aydogmus Z, Imre S, Gören AC, Pezzuto JM, et al. (2003) Brominated sesquiterpenes from the red alga Laurencia obtusa. J Nat Prod 66: 1505-1508.

17. Davyt D, Fernandez R, Suescun L, Mombrú AW, Saldaña J, et al. (2001) New sesquiterpene derivatives from the red alga Laurencia scoparia. Isolation, structure determination, and anthelmintic activity. J Nat Prod 64: 1552-1555.

18. Jung WK, Choi I, Oh S, Park SG, Seo SK, et al. (2009) Anti-asthmatic effect of marine red alga (Laurencia undulata) polyphenolic extracts in a murine model of asthma. Food Chem Toxicol 47: 293-297.

19. Kurata K, Taniguchi K, Agatsuma Y, Suzuki M (1998) Diterpenoid feedingdeterrents from Laurencia saitoi. Phytochemistry 47: 363-369.

20. Dembitsky VM, Tolstikov GA (2004) Natural halogenated sesquiterpens from marine organisms, chemistry for sustainable development 12: 1-12.

21. Erickson KL (1983) Marine natural products. Academic Press.

22. Suzuki M, Kurosawa E, Irie T (1970) Spirolaurenone, a new sesquiterpenoid containing bromine from Laurencia glandulifera Kützing. Tetrahedron Lett 11 4995-4998.

23. Li XD, Ding W, Miao FP, Ji NY (2012) Halogenated chamigrane sesquiterpenes from Laurencia okamurae. Magn Reson Chem .

24. Ji NY, Li XM, Li K, Ding LP, Gloer JB, et al. (2007) Diterpenes, sesquiterpenes, and a $\mathrm{C} 15$-acetogenin from the marine red alga Laurencia mariannensis. J Nat Prod 70: 1901-1905

25. Li XD, Miao FP, Li K, Ji NY (2012) Sesquiterpenes and acetogenins from the marine red alga Laurencia okamurai. Fitoterapia 83: 518-522.

26. Liang Y, Li XM, Cui CM, Li CS, Sun H, et al. (2012) Sesquiterpene and acetogenin derivatives from the marine red alga Laurencia okamurai. Ma Drugs 10: 2817-2825.

27. Ji NY, Li XM, Zhang Y, Wang BG (2007) Two new halogenated chamigranetype sesquiterpenes and other secondary metabolites from the marine red alga Laurencia okamurai and their chemotaxonomic significance. Biochem Syst Ecol 35: 627-630.

28. Liang Y, Li XM, Cui CH, Li CS, Wang GW (2009) A new rearranged chamigrane sesquiterpene from Laurencia okamurai. Chinese Chemical Letters 20: 190192.

29. de Nys R, Coll JC, Bowden BF (1993) Tropical marine algae IX A new sesquiterpenoid metabolite from the red alga Laurencia mariannensis. Aust $J$ Chem 46: 933-937.

30. Li XD, Miao FP, Yin XL, Liu JL, Ji NY (2012) Sesquiterpenes from the marine red alga Laurencia composita. Fitoterapia 83: 1191-1195.

31. Ji NY, Li XM, Li K, Gloer JB, Wang BG (2008) Halogenated sesquiterpenes and nonhalogenated linear $\mathrm{C} 15$-acetogenins from the marine red alga Laurencia composita and their chemotaxonomic significance. Biochem Syst Ecol 36: 938-941.

32. Ji NY, Li XM, Wang BG (2010) Sesquiterpenes and other metabolites from the marine red alga Laurencia composita (Rhodomelaceae). Helv Chim Acta 93 2281-2286.

33. Sims JJ, Lin GHY, Wing RM (1974) Marine natural products X elatol, a halogenated sesquiterpene alcohol from the red alga Laurencia elata Tetrahedron Lett 15: 3487-3490.

34. Lhullier C, Donnangelo A, Caro M, Palermo JA, Horta PA, et al. (2009) Isolation of elatol from Laurencia microcladia and its palatability to the sea urchin Echinometra lucunter. Biochem Syst Ecol 37: 254-259.

35. Gonzalez AG, Darias J, D'iaz A, Fourneron JD, Martin JD, et al. (1976) Evidence for the biogenesis of halogenated chamigrenes from the red alga Laurencia obtusa. Tetrahedron Lett 17: 3051-3054.

36. Vairappan CS (2003) Potent antibacterial activity of halogenated metabolites from Malaysian red algae, Laurencia majuscula (Rhodomelaceae, Ceramiales). Biomol Eng 20: 255-259.

37. Dos Santos AO, Veiga-Santos P, Ueda-Nakamura T, Filho BP, Sudatti DB, et al. (2010) Effect of elatol, isolated from red seaweed Laurencia dendroidea, on Leishmania amazonensis. Mar Drugs 8: 2733-2743.

38. Desoti VC, Lazarin-Bidóia D, Sudatti DB, Pereira RC, Alonso A, et al. (2012) Trypanocidal action of (-)-elatol involves an oxidative stress triggered by mitochondria dysfunction. Mar Drugs 10: 1631-1646.

39. Campos A, Souza CB, Lhullier C, Falkenberg M, Schenkel EP, et al. (2012) Anti-tumour effects of elatol, a marine derivative compound obtained from red algae Laurencia microcladia. J Pharm Pharmacol 64: 1146-1154.

40. Dias DA, Urban S (2011) Phytochemical studies of the southern Australian marine alga, Laurencia elata. Phytochemistry 72: 2081-2089. 
41. Blunt JW, Copp BR, Munro MHG, Norhcote, PT, Prinsep MR (2003) Marine natural products. Nat Prod Rep 20: 1-48.

42. Dorta E, Díaz-Marrero AR, Cueto M, D'Croz L, Maté JL, et al. (2004) Chamigrenelactone, a polyoxygenated sesquiterpene with a novel structural type and devoid of halogen from Laurencia obtusa. Tetrahedron Lett 45: 70657068.

43. Brito I, Cueto M, Díaz-Marrero AR, Darias J, San Martín A (2002) Oxachamigrenes, new halogenated sesquiterpenes from Laurencia obtusa. $J$ Nat Prod 65: 946-948.

44. Gonza'lez AG, Marti'n JD, Marti'n VS, Norte M, Pe'rez R (1982) Biomimetic approach to the synthesis of rhodolaureol and rhodolauradiol. Tetrahedron Lett 23: 2395-2398

45. Suzuki M, Kurosawa E, Furusaki A (1988) The structure and absolute stereochemistry of a halogenated chamigrene derivative from the red alga Laurencia species. Bull Chem Soc Jpn 61: 3371-3373.

46. Ji NY, Li XM, Li K, Wang BG (2009) Halogenated sesquiterpenes from the marine red alga Laurencia saitoi (Rhodomelaceae). Helv Chim Acta 92: 18731879.

47. Howard BM, Fenical W (1975) Structures and chemistry of two new halogencontaining chamigrene derivatives from Laurencia. Tetrahedron Lett 16: 1687.

48. Jongaramruong J, Blackman AJ, Skelton BW, White AH (2002) Chemical relationships between the sea hare Aplysia parvula and the red seaweed Laurencia filiformis from Tasmania. Aust J Chem 55: 275-280.

49. Suzuki M, Daitoh M, Vairappan CS, Abe T, Masuda M (2001) Novel halogenated metabolites from the Malaysian Laurencia pannosa. J Nat Prod 64: 597-602.

50. Juagdan EG, Kalidindi R, Scheuer PJ (1997) Two new chamigranes from an hawaiian red alga, Laurencia cartilaginea. Tetrahedron 53: 521-528.

51. Suescun L, Mombrú AW, Mariezcurrena RA, Davyt D, Fernández R, et al. (2001) Two natural products from the algae Laurencia scoparia. Acta Crystallogr C 57 286-288.

52. Francisco ME, Erickson KL (2001) Ma'iliohydrin, a cytotoxic chamigrene dibromohydrin from a Philippine Laurencia species. J Nat Prod 64: 790-791.

53. da Silva Machado FL, Ventura TL, Gestinari LM, Cassano V, Resende JA, et al. (2014) Sesquiterpenes from the Brazilian red alga Laurencia dendroidea J. Agardh. Molecules 19: 3181-3192.

54. Rucker R, Kretzuschmar U (1971) 9-Aristolen-1a-ol and 1,2,9,10-tetradehydroaristolane, new aristolane type sesquiterpenes. Liebigs Ann Chem 748: 214-217.

55. Ji NY, Li XM, Ding LP, Wang BG (2007) Aristolane sesquiterpenes and highly brominated indoles from the marine red alga Laurencia similis (Rhodomelaceae). Helv Chim Acta 90: 385-391.

56. Li CS, Li XM, Cui CM, Wang BG (2010) Brominated metabolites from the marine red alga Laurencia similis. Z. Naturforsch 65: 87-89.

57. Su S, Sun WS, Wang B, Cheng W, Liang H, et al. (2010) A novel brominated cuparene-derived sesquiterpene ether from the red alga Laurencia sp. J Asian Nat Prod Res 12: 916-920.

58. Kamada T, Vairappan CS (2013) New bioactive secondary metabolites from Bornean red alga, Laurencia similis (Ceramiales). Nat Prod Commun 8: $287-$ 288

59. Fraga BM (1997) Natural sesquiterpenoids. Nat Prod Rep 14: 145-162.

60. Kladi M, Vagias C, Papazafiri P, Furnari G, Serio D, et al. (2007) New sesquiterpenes from the red alga Laurencia microcladia. Tetrahedron 63: 76067611.

61. Yu XQ, He WF, Liu DQ1, Feng MT, Fang Y, et al. (2014) A seco-laurane sesquiterpene and related laurane derivatives from the red alga Laurencia okamurai Yamada. Phytochemistry 103: 162-170.

62. Davyt D, Fernandez R, Suescun L, Mombrú AW, Saldaña J, et al. (2006) Bisabolanes from the red alga Laurencia scoparia. J Nat Prod 69: 1113-1116.

63. de Carvalho LT, Fujii MT, Roque NF, Kato MJ, Lago JHG (2003) Aldingenin A, new brominated sesquiterpene from red algae Laurencia aldingensis. Tetrahedron Lett 44: 2637-2640.

64. de Carvalho LR, Fujii MT, Roque NF, Lago JH (2006) Aldingenin derivatives from the red alga Laurencia aldingensis. Phytochemistry 67: 1331-1335.

65. Conolly JD, Hill RA. (1991)Dictionary of Terpenoids, Volume 1, mono and sesquiterpenoids, Chapman and Hall, London, UK.
66. Zhan ZJ, Ying YM, Ma LF, Shan WG (2011) Natural disesquiterpenoids. Nat Prod Rep 28: 594-629.

67. Kladi M, Vagias C, Furnari G, Moreau D, Roussakis C, et al. (2005) Cytotoxic cuparene sesquiterpenes from Laurencia microcladia. Tetrahedron Lett 46 5723-5726.

68. Mao SC, Guo YW (2006) A laurane sesquiterpene and rearranged derivatives from the Chinese red alga Laurencia okamurai Yamada. J Nat Prod 69: 1209 1211.

69. Srikrishna A, Khan IA, Ramesh Babu R, Sajjanshetty A (2007) The first tota synthesis of $( \pm)$-laurokamurene B. Tetrahedron 63: 12616-12620.

70. Irie T, Suzuki T, Yasunari Y, Kurosawa E, Masamune T (1969) Laurene, sesquiterpene hydrocarbon from Laurencia species. Tetrahedron 25: 459-468.

71. Wratten SJ, Faulkner DJ (1977) Metabolites of the red alga Laurencia subopposita. J Org Chem 42: 3343-3349.

72. Alarif WM, Al-Lihaibi SS, Ayyad SE, Abdel-Rhman MH, Badria FA (2012) Laurene-type sesquiterpenes from the Red Sea red alga Laurencia obtusa as potential antitumor-antimicrobial agents. Eur J Med Chem 55: 462-466.

73. Yamamura S, Hirata Y (1963) Structures of aplysin and aplysinol, naturally occurring bromo-compounds. Tetrahedron 19: 1485-1496.

74. Elzen GW, Williams HJ, Vinson SB (1984) Isolation, identification, and bioassay of cotton synomones mediating searching behavior by parasitoid Campoletis sonorensis. Journal of Chemical Ecology 10: 1251-1264.

75. Mao S, Guo Y (2005) Cuparene-Derived sesquiterpenes from the Chinese red alga Laurencia okamurai YAMADA Helv Chim Acta 88: 1034-1039.

76. Goldsmith J, John TK, Kwong, CD, Painter III GR (1980) Preparation and rearrangement of trichothecane-like compounds. Synthesis of aplysin and filiformin. J Org Chem 45: 3989-3993.

77. Shizuri Y, Yamada K (1985) Laurebiphenyl, a dimeric sesquiterpene of the cyclolaurane-type from the red alga Laurencia nidifica. Phytochemistry 24 1385-1386.

78. Liang Y, Li XM, Li CS, Sun H, Wang BG (2014) Laurane-, cyclolaurane-, and cuparane-type sesquiterpenes from the marine red alga Laurencia okamurai. Nat Prod Commun 9: 323-324.

79. Sun J, Han LJ, Shi DY, Fan X, Wang SJ et al. (2005) Sesquiterpenes from red alga Laurencia tristicha. Chin Chem Lett 16: 1611-1614.

80. Nemoto H, Nagamochi M, Ishibashi H, Fukumoto K (1994) A remarkable substituent effect on the enantioselectivity of tandem asymmetric epoxidation and enantiospecific ring expansion of cyclopropylidene alcohols: a new enantiocontrolled synthesis of (-)-debromoaplysin and (-)-aplysin. J Org Chem 59: 74-79.

81. Ji NY, Li XM, Li K, Ding LP, Wang BG (2008) Laurane-derived sesquiterpenes from the marine red alga Laurencia tristicha (Rhodomelaceae). Nat Prod Res 22: $715-718$

82. Kaslauskas R, Murphy PT, Quin RJ, Wells RJ (1976) New laurene derivatives from Laurencia filiformis. Aust J Chem 29: 2533-2539.

83. Dias DA, White JM, Urban S (2009) Laurencia filiformis: phytochemical profiling by conventional and HPLC-NMR approaches. Nat Prod Commun 4: 157-172.

84. Appleton DR, Babcock RC, Copp BR (2001) Novel tryptophan-derived dipeptides and bioactive metabolites from the sea hare Aplysia dactylomela. Tetrahedron 57: 10181-10189.

85. Kçnig GM, Wright AD (1994) New C15 Acetogenins and sesquiterpenes from the red alga Laurencia sp. cf. L. gracilis. J Nat Prod 57: 477-485.

86. Kladi M, Xenaki H, Vagias C, Papazafiri P Roussis V (2006) New cytotoxic sesquiterpenes from the red algae Laurencia obtusa and Laurencia microcladia Tetrahedron 62: 182189

87. Iliopoulou D, Roussis V, Pannecouque C, De Clercq E, Vagias C (2002) Halogenated sesquiterpenes from the red alga Laurencia obtusa. Tetrahedron 58: 6749-6755

88. AydoÄŸmuÅŸ Z, Imre S, Ersoy L, Wray V (2004) Halogenated secondary metabolites from Laurencia obtusa. Nat Prod Res 18: 43-49.

89. Brennan MR, Erickson KL (1982) Austradiol acetate and austradiol diacetate, 4,6-dihydroxy-(+)-selinane derivatives from an Australian Laurencia sp. J Org Chem 47: 3917-3921.

90. Kazlauskas R, Murphy PT, Wells RJ, Daly JJ, Oberhansli WE (1977) Heterocladol, a halogenated selinane sesquiterpene of biosynthetic significance from the red alga Laurencia filiformis: Its isolation, crystal structure and absolute configuration. Australian Journal of Chemistry 30; 2679 - 2687

91. Guella G, Skropeta D, Mancini I, Pietra F (2002) The First 6,8-cycloeudesmane 
Citation: Shaza M Al-Massarani (2014) Phytochemical and Biological Properties of Sesquiterpene Constituents From the Marine Red Seaweed Laurencia: A Review. Nat Prod Chem Res 2: 147. doi:10.4172/2329-6836.1000147

sesquiterpene from a marine organism: The red seaweed Laurencia microcladia from the Baia di Calenzana, Elba island. Z. Naturforsch, B: Chem Sci 57: 11471151.

92. Suzuki M, Takahashi Y, Mitome Y, Itoh T, Abe T, et al. (2002) Brominated metabolites from an Okinawan Laurencia intricata. Phytochemistry 60: 861-867.

93. Reward BM, Fenical W (1976) a- and ß-snyderol; new bromo-monocyclic sesquiterpenes from the seaweed Laurencia. Tetrahedron Lett 17: 41-44.

94. Su H, Shi DY, Li J, Guo SJ, Li LL, et al. (2009) Sesquiterpenes from Laurencia similis. Molecules 14: 1889-1897.

95. Kuniyoshi M, Marma MS, Higa T, Bernardinelli G, Jefford CW (2001) New bromoterpenes from the red alga Laurencia luzonensis. J Nat Prod 64: 696700 .

96. Kuniyoshi M, Wahome PG, Miono T, Hashimoto T, Yokoyama M, et al. (2005) Terpenoids from Laurencia luzonensis. J Nat Prod 68: 1314-1317.

97. Su H, Yuan ZH, Li J, Gua SJ, Deng LP, et al. (2009) Sesquiterpenes from the marine red alga Laurencia saitoi. Helv Chim Acta 92: 1291-1297.

98. Makhanu DS, Yokoyama M, Miono T, Maesato T, Maedomari M, et al. (2006) New sesquiterpenes from the Okinawan red alga Laurencia luzonensis. Bull Fac Sci Univ Ryukyus 81: 115-120.

99. Vairappan CS, Kamada T, Lee WW, Jeon YJ (2013) Anti-inflammatory activity of halogenated secondary metabolites of Laurencia snackeyi (Weber-van Bosse) Masuda in LPS-stimulated RAW 264.7 macrophages. J Appl Phycol 25: 1805-1813

100.Wijesinghe WA, Kim EA1, Kang MC1, Lee WW1, Lee HS2, et al. (2014) Assessment of anti-inflammatory effect of $5 \hat{\imath}^{2}$-hydroxypalisadin B isolated from red seaweed Laurencia snackeyi in zebrafish embryo in vivo model. Environ Toxicol Pharmacol 37: 110-117.
101.Su H, Yuan Z, Li J, Guo S, Han L, et al. (2009) [Studies on chemical constituents of Laurencia saitoi]. Zhongguo Zhong Yao Za Zhi 34: 871-874.

102. Guella G, Skropeta D, Mancini I, Pietra F (2003) Calenzanane sesquiterpenes from the red seaweed Laurencia microcladia from the Bay of Calenzana, Elba Island: acid-catalyzed stereospecific conversion of calenzanol into indeneand guaiazulene-type sesquiterpenes. Chemistry 9: 5770-5777.

103. Brito I, Cueto M, Dorta E, Darias J (2002) Bromocyclococanol,a halogenated sesquiterpene with a novel carbon skeleton from the red alga Laurencia obtusa. Tetrahedron Lett 43: 2551-2553.

104. Fan W, White JB (1993) Total synthesis of (+-.)-africanol and (+-)-isoafricanol. J Org Chem 58: 3557-3562.

105. Wright AD, Goclik E, König GM (2003) Three new sesquiterpenes from the red alga Laurencia perforata. J Nat Prod 66: 435-437.

106. Vairappan CS, Suzuki M, Ishii T, Okino T, Abe T, et al. (2008) Antibacteria activity of halogenated sesquiterpenes from Malaysian Laurencia spp. Phytochemistry 69: 2490-2494.

107. Erickson KL, Beutler JA, Gray GN, Cardellina JH 2nd, Boyd MR (1995) Majapolene A, a cytotoxic peroxide, and related sesquiterpenes from the red alga Laurencia majuscula. J Nat Prod 58: 1848-1860.

108. Monde K, Taniguchi T, Miura N, Vairappan CS, Suzuki M (2006) Absolute configurations of brominated sesquiterpenes determined by vibrational circular dichroism. Chirality 18: 335-339.

109. da Silva Machado FL, Pacienza-Lima W, Rossi-Bergmann B, de Souza Gestinari LM, Fujii MT, et al. (2011) Antileishmanial sesquiterpenes from the Brazilian red alga Laurencia dendroidea. Planta Med 77: 733-735. 